\title{
Bizans'ın Çöküşü, Osmanlı'nın Yükselişi: Tarihsel Romanda Fetih Öncesi (1875-2020)*
}

\author{
DR. ÖĞR. GÖRV. HAKAN DEĞİRMENCI'**
}

\section{Öz}

Türk edebiyatında İstanbul'un fethini ele alan romanların geçmişi, Türk romanının mazisi kadar eskidir. İlki 1875'te yayımlanan Hüseyin Fellâh romanıyla başlayan fetih romancılığı, Tanzimat ve II. Meşrutiyet dönemlerinde devam etmiş, Cumhuriyet'ten itibaren Tek Parti, Demokrat Parti dönemlerinde de ele alınmış ve 1970'lardan itibaren gayet nitelikli ürünlerle zirveye çıkmıştır. 2000'lerden itibaren ülkede yaşanan siyasal ve toplumsal dönüşüme paralel olarak fethe duyulan alakayı para kazanma aracı olarak gören bir zümre oluşmuş ve ortaya daha az nitelikli romanlar çıkmıştır. Nihayetinde fetih meselesi, hangi dikkat ve malumat seviyesinde olursa olsun, herkesin ilgisini çeken popüler bir konudur.

$\mathrm{Bu}$ çalışmada, kurgusal metinlere yansıyan yönüyle hem Osmanlı Devleti ve toplumu bakımından hem de Bizans Devleti ve genel olarak Hristiyan dünyası bakımından fethin öncesine yönelik değerlendirmeler yapılacaktır. Surların her iki tarafında yaşanan siyasi, askerî ve ekonomik koşular ve bunların insani ve sosyolojik süreçler bağlamında romanlara yansımasıyla ilgili tahliller, fethe giden süreci daha iyi anlamamıza vesile olacaktır.

Anahtar sözcükler: Fatih, Mehmet II, İstanbul, fetih, roman

\section{THE COLLAPSE OF BYZANTINE, THE RISE OF OTTOMAN: BEFORE CONQUEST IN} HISTORICAL ROMAN (1875-2020)

\section{Abstract}

The history of the novels that deal with the conquest of Istanbul in Turkish literature is as old as the past of the Turkish novel. The conquest novel started with the novel Süleyman Musli, published in 1875, Tanzimat and II. It continued during the Constitutionalist Periods, and was handled during the Single Party and Democratic Party periods from the Republic and has reached the top with highly qualified products since the 1970s. In parallel with the political and social transformation experienced in the principle since 2000s, a branch that saw the relevance for the conquest as a means of earning money has also been formed and products that we can describe as a market novel have emerged. Ultimately, the question of conquest is a popular topic that attracts everyone's attention, no matter what level of attention and knowledge.

In this study, pre-conquest evaluations will be made both in terms of the Ottoman State and society as well as the Byzantine State and the Christian world in general, as reflected in the fictional texts. The analysis of political, military and economic conditions on both sides of the

\footnotetext{
* Bu makale, 2014 yılında Marmara Üniversitesi Türkiyat Araştırmaları Enstitüsü’nde tamamlanmış “Başlangıçtan Günümüze Türk Romanında İstanbul'un Fethi" isimli doktora tezinden türetilmiştir.

** Aydın Adnan Menderes Ün. Eğitim Fak. Türkçe Eğ. Böl. hakan.degirmenci@adu.edu.tr, Orcid: 0000-0002-1208-6628 Gönderim tarihi: 22.06 .2020

Kabul tarihi: 25.09.2020
} 
walls and their reflection on novels in the context of human and sociological processes will help us to better understand the process leading to the conquest.

Keywords: Fatih, Mehmet II, Istanbul, conquest, novel.

\section{GİRIŞ}

Tarih ile edebiyat arasında çok eskilere dayanan bir ilişki vardır. Tarihin edebiyat için bir "malzeme" ve "ilham kaynağı", edebî eserlerin de tarih için zaman zaman “vesika" değeri taşıdığı bilinen bir gerçektir (Dayanç, 2009, s. 1875). Nihayetinde geçmişin gelecek nesillere aktarılması için tarihçiye ihtiyaç vardır. Romancı ise tarihçilerin verdiğ $i$ bilgiye göre, elindeki diğer sosyolojik, antropolojik, ekonomik ve siyasi intibalar ve gözlemlerle edebî metni oluşturur.

Burada romancının tarihte cereyan eden bir hadisenin ne kadar aslına yaklaştığ 1 ve eserinde nasıl işlediği sorunu gündeme gelmektedir. Oysa bu tartışma daha romanciya gelmeden önce tarihçiler arasında da tamamlanmış değildir. Çünkü orada da "gerçekte ne olduğu" bilgisi ile "tarihçinin neyi gördüğ̈̈" ve üzerine "nasıl yorumladığı" tartışmaları yapılagelmektedir. "Görmek" tarihçinin kapasitesine, "yorumlamak" ise çok daha geniş bir takım insani ve toplumsal amillerle alakalı bir eylem olduğuna göre, hakikat üzerine tartışmalar tarihçiler tarafından bile tamamlanmamış bir sorundur.

$\mathrm{Bu}$ çalışmamızda tarih-edebiyat-hakikat kurgu gibi tartışmalar girmeden, tarihi romanın tarih ile edebiyat arasında bir yerlerde, ama daha çok ve öncelikle bir sanat eseri olduğu yaklaşımından hareket edeceğiz.

Türk edebiyatında, tarihsel romanın mazisi Türk romanının tarihçesi kadar eskidir. Namık Kemal'in Cezmi'sinden ve Ahmet Mithat'tan itibaren Tanzimat ve Meşrutiyet dönemlerinde, daha sonra Cumhuriyet döneminde, Çok Partili dönemde ve 80 sonrası Türk romanında tarihi roman türü, romancılar ve okurlar için her dönemde ilgi çekici olmuştur. Bu roman türü içinde Osmanlı tarihiyle ilgili olan romanlar, Kurtuluş Savaşı konulu romanlardan sonra en çok rağbet gören eserler olmuştur. Osmanlı tarihiyle ilgili olarak ise kuruluş devrini, fetret dönemini, Cem Sultan'ı, İmparatorluğun son bir asrını, Balkan Savaşlarını, saraydaki şehzadelerin ve paşaların aşklarını, valide sultanlar arasındaki entrikaları anlatan romanlar gibi, İstanbul'un fethini anlatan romanlar da dikkat çekici bir yere sahiptir. ${ }^{1}$

İstanbul'un fethi gibi sadece Türk ve İslâm tarihi açısından değil, bütün dünya tarihi bakımından da önem taşıyan büyük hadise, Türk edebiyatının her türüne konu olmuş, başta roman olmak üzere şiir ve tiyatroda da sıkça işlenmiştir. ${ }^{2}$

\footnotetext{
${ }^{1}$ Konuyla ilgili olarak Argunşah (1990) çalışmasında konularına göre romanları tasnif etmiş, sonra da yayım yıllarına göre romanları sıralamıştır.

${ }^{2}$ Fetih ve Fatih konulu romanlar üzerinde dikkat çekici üç çalışma bulunmaktadır: Bunlardan ilki, İstanbul'un Fethi ve Fatih adlı kitaptır. Bu çalışmanın içinde Zeki Taştan'ın hazırladığ “"Türk Romanında İstanbul'un Fethi ve Fatih"2 başlığı altında bir bölüm bulunmaktadır. Taştan, çalışmasında İstanbul'un fethine temas eden ilk romanlara kadar uzanmış, son olarak da 1999'da yayımlanan Kara Büyülü Uyku romanına kadar gitmiştir. Üzerinde durulması gereken diğer çalışma Halim Kara'nın Osmanlının Edebi Temsili: Türk Romanında Fatih ${ }^{2}$ adlı çalışmasıdır. Bu eserde on iki tarihsel roman üzerinden Fatih'in karakterize edilişi değerlendirilmiştir. Yazarın bu çalışmasında yararlandığı romanlardan sonuncusu 2009'da yayımlanmış olan Kuşatma 1453'tür. Konuyla ilgili dikkat çeken son çalışma Sema Uğurcan'ın Edebiyatımız-I çalışmasında yer alan "Fatih Sultan Mehmet'in Romanı"2 adlı makalesidir. Makalede konuyla ilgili
} 
İstanbul'un fethine temas eden ilk romanlar Ahmet Mithat Efendi'nin 1875 tarihli Hüseyin Fellah ve 1877 tarihli Süleyman Muslî romanlarıdır. Tanzimat döneminden itibaren Meşrutiyet, Cumhuriyet, Çok Partili dönem ve 1980'den günümüze kadar Fetih ve Fatih hakkında ellinin üzerinde roman yayımlanmıştır. Bunlar arasında popüler kültüre ve hamasete yönelik olanlarından, fethin karanlık noktalarını aydınlatmaya yönelik olanlarına kadar pek çok önemli roman kitapçlardaki yerini almıştır.

İstanbul'un fethinin Türk romanında ne şekilde ele alındığını ortaya koyarken, fethin siyasî, sosyal ve iktisadî arka planının romanlarımıza yansımasının nasıl olduğu konusunun ortaya konulması hayati önem taşımaktadır. Bu nedenle öncelikle muhasara öncesinde Osmanlı ve Bizans tarafında sözünü ettiğimiz koşulların insani ve toplumsal süreçler bakımından romanımıza nasıl yansıdığı ortaya konulmaya çalışılacaktır.

\section{FETİH ÖNCESI OSMANLI DEVLETI}

\subsection{Siyasi Durum}

İstanbul'un fethini ele alan romanların pek çoğunda hadiseler kimi zaman Sultan II. Murat devrinden, kimi zaman da II. Mehmet' in doğumundan başlatılmaktadır. Bu gruptaki romanlarda, II. Mehmet'in doğumu, çocukluk dönem, şehzadelik devri anlatılmakta, uzun uzun aldığı eğitime odaklanılmakta, tahta ilk çıkışı, yeniden Manisa'ya dönüşü ve bu esnada dönen saray içi entrikalara değinilmektedir. ${ }^{3}$

Şubat 1451 'de babası Sultan II Murat'ın vefat haberini aldığında Şehzade Mehmet, Manisa Valiliği görevinde bulunmaktadır (Saraçoğlu, 2010, s. 20). Sadrazam Çandarlı Halil Paşa, Padişahın ölüm haberini gizli tutmuş, el altından habercisini Manisa'ya göndermiştir. Habercinin getirdiği mektupta Çandarlı Halil Paşa şöyle demiştir: “Cennet mekân ulu pederiniz Sultan Murat Han, Allah'ın rahmetine kavuşmuşlardır. Bir an önce Edirne'ye gelmeniz devletin bekası için hayırlı olacaktır. Kulunuz Halil Paşa." (Şahin, 2012, s. 83).

Kaderin ikinci kez taht nasip ettiği genç padişah, derhal bir Arap atına atlamış ve erkânına “Beni seven arkamdan gelsin.” (Bahar, 2012: 84) diyerek Edirne'ye doğru yola çıkmıştır. Altı yıl evvel onu tahttan indirenler şimdi sevinç ve coşku içinde gelişini kutlamıştır. Başta Halil Paşa olmak üzere, herkeste bir tedirginlik vardır. Fakat genç padişah daha tahta oturduğu ilk gün “Vezirlerim benden niçin bu kadar uzak dururlar?" (Saraçoğlu, 2010: 22) diyerek gönül almasını bilmiştir. Çünkü onun tek hedefi İstanbul'dur ve bu yüzden şimdilik geçmişte yaşananları unutmuş gibi gözükmektedir. Diğer taraftan bu vezirin kudretini geçmişte saltanattan hal edilmek suretiyle bizzat gördügünden, mevkiini tahkim edinceye kadar, onunla hoş geçinmek istemiştir (Y1lmaz, 2011, s. 32).

II. Mehmet tahta çıktığı zaman Anadolu'da kendine rakip olabilecek potansiyele sahip Karamanoğulları ile İsfendiyaroğulları kalmıştır. Batı'da ise Sırbistan Osmanlı Devleti'ne haraç

romanların, yayımlandığı döneminin siyasi ve sosyal şartları içinde nasıl şekillendiğine dair analizler yapılmış, ayrıca fetihle ilgili sinırlı mevzularda tematik değerlendirmelere de gidilmiştir.

${ }^{3}$ Fethi öncesi siyasi panoramanın sağlıklı bir şekilde ortaya konulabilmesi için, meseleyi II. Mehmet'in tahta çıkışından itibaren ele almayı uygun bulmaktayız. Hem konuyu derinliklerde kaybetmemek, hem de dağıtmamak adına böylesi bir tavrın gerekliliğine inanıyoruz. 
ödeyen bir devlet, Eflak Voyvodası Drakula ise her yıl belli miktarda vergi ödeyen bir beylik konumundadır: “Bizans'tan cülusunu tebrik için özel bir elçi geldiği gibi, Venedik'ten, Galata'daki bağımsız beylikten, Sakız, Midilli ve Rodos şövalyelerinden ve Macar Kralı Jan Hunyad'dan ve Bizans İmparatorunun kardeşleri olan Mora Despotları Dimitrius ve Tomas'tan özel sefirler gelip, yeni padişahı tebrik etmişlerdir." (Saraçoğlu; 2010: 29).

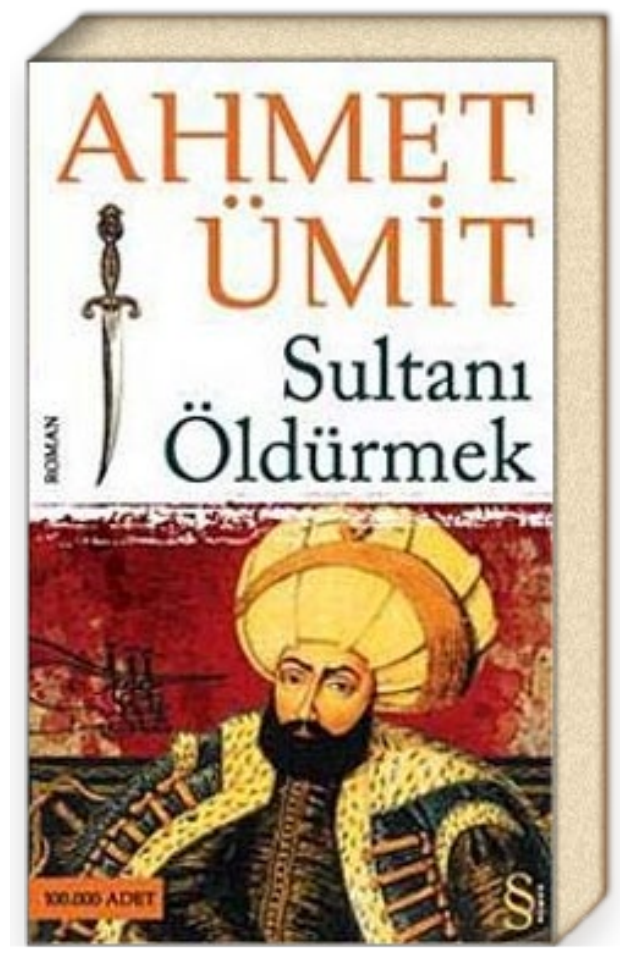

Romanların tamamında genç padişahın, tahta çıar çıkmaz son derece aktif bir diş politika içinde olduğunu görmekteyiz. Bu politika, Batı'ya karşı son derece barışçıl ama Doğu'ya karşı saldırgancadır. Padişahın buradaki amacı, asıl niyetini gizlemek ve bu arada çocukluğundan beri hayalini kurduğu fethin hazırlıklarını yapabileceği ortamı sağlamaktır. Bu anlamda önce Sırp ve Macarlarla iki yıllık bir anlaşma yaparak hem Batı sınırları güvence altına alır hem de Bizans'ı yalnızlaştırır. Öte yandan Bizans'a sığınan Şehzade Orhan'ın masraflarına mukabil Bizans'a ödenen verginin arttırılması talebini kabul eder. Zira Şehzade Orhan'ın serbest kalması durumunda ülkede karışıklık doğabilirdi (Bahar, 2012, s. 35). Rum Ateşi romanında Bizans İmparatoru Konstantin Dragazes'in “Bizanslılar öteden beri ellerinde bir Türk şehzadesi bulundurmayı âdet edinmişlerdir." (Alpar, 1966, s. 11) sözü de bu anlamda dikkat çekicidir.

Doğu'da, yani Anadolu'da ise iki yüz seneden beri Osmanoğulları ile kıyasıya bir rekabet içinde olan Karamanoğulları, genç bir padişahın varlığını fırsata çevirme hesapları yapmaya başlamıştır. Karaman Beyi İbrahim'e bir ders verme lüzumu gören II Mehmet, Karaman’ın üzerine önce Anadolu Beylerbeyi İshak Paşa'yı gönderir, ardından daha büyük bir ordu ile kendisi Gelibolu'dan yola çıkar ve Bursa'ya kadar gelir. Anadolu'daki halkın Osmanlı ordusuna teveccühünü gören Karamanoğlu İbrahim, geri adım atar ve bir anlaşma talep eder. Ordusunu yıpratmaması gerektiğini iyi bilen II. Mehmet, zaruretten anlaşmayı kabul eder ve seferi yarım bırakır. En azından şimdilik Karaman tehlikesi defedilmiştir.

Ele aldığımız romanlarda, fetih öncesi siyasi ilişkiler bağlamında Karaman tehlikesinden çok, Bizans'la ilişkiler üzerinde daha çok durulmuş, fethe odaklı bir uluslararası ilişkiler ağı öne çıkarılmıştır. II. Mehmet'in İstanbul'u niye bu kadar çok istediği konusu, pek çok romanda İstanbul'un siyasi, jeopolitik, ekonomik ve psikolojik değeri bağlamında sıkça işlenmiştir.

Sultan'ı Öldürmek romanında, Tahir Hakkı Bentli, gelişime açık, meraklı, geçmişi kurcalamaktan hoşlanan gençlere vaaz eden bir tarih profesörüdür. Meseleleri, resmi tarihin dışına çıkarak anlatmayı sevse de o yine de romanda eski neslin temsilcisidir. Vatanseverdir ve tarihi şahsiyetlere pek laf söyletmez:

Sadece kentin zenginliklerinin ele geçirilmesi değildir amaçlanan, büyük bir engelin ortadan kaldırılmasıydı. Osmanlı Devleti'nin imparatorluğa dönüşmesinin önündeki engellerden biriydi Konstantiniye. Özellikle II. Mehmet zamanında bölge tümüyle 
Osmanlı'nın hâkimiyetine girmişti. Konstantiniye, bu toprakların ortasında bir adacık gibi kalmıştı. Cihanşumul bir devlet kurmak isteyen II. Mehmet için, her an arkadan hançerlenebileceği bir düşman adası... Osmanlı'nın aşil topuğu... Ancak bu ada ele geçirildikten sonra daha büyük bir sefere çıabilirdi genç padişah. (Ümit, 2012, s. 261).

Fethin siyasi ve jeopolitik önemine dikkat çeken bu konuşmanın son cümlesinde, yazaranlatıc1, Fatih'in daha büyük hedefleri olduğuna, nihai hedefin Roma olacağına gönderme yapmaktadır. Tahir Hakkı Hoca, fethi bir taraftan da kişisel nedenlere bağlar. Ona göre, "II Mehmet, Varna Savaşı'nı kazanan babasının gölgesinde kalmamak için şehri fethetmek zorundadır. Yoksa tahttan bile olabilecektir." (Ümit, 2012, s. 262).

Muhasarayı hem siyasi hem de kişisel nedenlere bağlama şeklindeki bir tavır Fatih Sultan Mehmet Han romanında da vardır. Anlatıcıya göre II. Mehmet'in amac1, “Tuna'nın güneyindeki Balkan toprakları ile Fırat'ın batısındaki Anadolu topraklarını alarak, büyük dedesi Yıldırım Beyazıt'ın oluşturmaya çalıştı̆̆ı merkeziyetçi imparatorluğu kurmaktı." (Şahin, 2012: 84). Böylesine emperyal bir tutkuyla muhasaraya kilitlenen II. Mehmet, birinci iktidarı döneminde beceriksiz olarak görülen imajını silecek, mağrur Bizans'ı yok ederek rüştünü ispatlamış olacaktır. Aynı romanda, 3. tekil anlatıcı parça parça pek çok yerde muhasaranın nedenleri üzerinde izahat yapmıştır. Bunları özetlemek gerekirse, İstanbul'un Osmanlı güvenliğini tehlikeye düşürmesi, Osmanlı'nın toprak bütünlügünü bozması, geçişlerde sıkıntılara neden olması, şehrin konumunun kara ve deniz ticareti bakımından hayati derecede önemli olması, saltanat iddiasında bulunan şehzadeleri koruyup kollayarak devamlı bir iç savaş tehdidinde bulunması, Anadolu beyliklerini Osmanlı'ya kışkırtması ve Osmanlı'ya karşı Haçlı seferlerini teşvik etmesi sıralanabilir (Şahin, 2012, s. 133).

Hocaefendi'nin Sandukası romanında fethin gerekçesi tamamen ekonomik kaygılara bağlanmıştır. Anlatıcıya göre Sultan Mehmet, İstanbul'daki Venedikli ve Cenevizlilerin alışverişteki ayrıcalığını dönüştürerek, Doğu-Batı arasındaki ticareti kendi denetimi altına almak istemektedir. Sulatan Mehmet, böylece ticareti hem geliştirecek hem de kendi kontrolü altında tutarak tacının kudretini arttıracaktır (Kongar, 1999, s. 32).

Dünyanın İlk Günü romanında, okuyucu II. Mehmet'i, sade Osmanlı Devleti'nin padişahı değil, bütün evrensel değerlerin peşinde, dünyayı kurtarmaya niyetli, daha cihanşümul bir vasıfta bulmaktadır. O, şahsi doktoru Yakup Paşa ve veziri Zağanos Paşa ile İbn-i Sina'nın El-Kanun'unu tartışan, bu eserin Sorbonne nüshalarına bile ulaşıp okuyan, Er-Razi'nin kızamık hakkındaki fikirlerini müzakere eden bir hekim, çocukluğunda Yunan masallarını okumuş, gençliğinde fars şiirleriyle gelişmiş donanımlı bir sanatçı ve Semerkant rasathanelerinde yapılan çalışmaları takip eden bir fen adamıdır. Bir gün vüzera ile muhasaranın planlarını yaparken, hayalindeki İstanbul'u şöyle anlatmıştır:

Ama benim hayal ettiğim yepyeni bir dünya, yepyeni bir merkez. Bütün dünyanın tek bir noktada toplandığı, Doğu'nun ve Batı'nın merkezi olan bir imparatorluk. Peygamberin Mekke'si gibi, Abbasilerin Bağdat'ı, İskender'in Halep'i, Selahaddin'in Kudüs'ü, Sezar'ın Roma'sı gibi bir şehir. Allah'ın emrinde, Hakk'ın hizmetinde, bütün insanların mutlulukla yaşadığı, bütün ilimlerin en üst seviyeye çıkarıldığı, cihana emsal olacak bir şehir. (Akman, 2012, s. 238). 
$\mathrm{Bu}$ romanda anlatıcl, genel olarak bazı insanların Doğu ve Batı diye kültürleri kalın çizgilerle ikiye ayırdıklarını, ama bunu yapay bir çizgi olduğunu, Müslümanlık, Hristiyanlık ve Yahudiliğin yüzyıllarca iç içe yaşadığını, hepsinin birbirinden etkilendiğini sıkça vurgulamaktadır. Anlatıcı-kahramana göre yeryüzünde bir karmaşa hüküm sürmekte ve bu kültürler tek bir idare tarafından yönetilmezse, birbirine zarar verecektir (Akman. 2012, s. 480). Artık Kudüs ve Kahire'nin yerini Konstantinapol'un alması gerekmektedir. II. Mehmet'in kuşatmaya bu kadar önem vermesinin nedeni de budur.

Aynı bakış açısı Fatih-1453 romanında da karşımıza çıkmaktadır. Anlatıcıya göre zulmün ve karanlığın vadesi dolmuş, insanlar huzuru, barışı ve mutluluğu hak etmektedir. Bunun için önce "her kötülüğün anası" haline gelmiş İstanbul kurtarılmalıdır (Bilgin, 2010, s. 236).

Bazı romanlarda da Osmanlı Devleti'nin kaderi tamamen İstanbul'a bağlanmıştır. Sultan'ı Öldürmek romanında Sultan Mehmet, çadırların arasında, öbek öbek yakılmış ateşlerin başında toplanan askerlerin arasında gezinirken karşımıza çıkmaktadır. Çoğunun adını bile bilmediği bu askerlerin arasında dolanırken, çok iyi sezdiği bir hakikatle yüzleşmektedir. Zira kendi hayatı ve devletinin kaderi bu tanımadığı askerlerin elindedir. Anlatıcı, bu kısımda iç monolog ve bilinç akışı tekniğiyle sultanın ürperişlerini dışa vurmaktadır:

Bir buçuk asır önce Söğüt'te doğan umut, büyüyerek yerküreyi kaplayacak mıydı, yoksa kaynağı cılız ırmaklar gibi bu Ortaçağ kalesinin görkemli surlarının önünde kuruyup gidecek miydi? Tam bu noktada, aysız gecenin altında karanlık bir heyula gibi yıkılıp üzerine gelen Konstantiniye bakar Mehmet ve 'Ey bütün dünyanın arzuladığ 1 şehir! Ya ben seni alacağım, ya da sen beni' diye mırıldanır (Ümit, 2012, s. 225).

Başka romanda kurmaylarına nasihat eden II. Mehmet, "Bu şehri ele geçirmedikçe, devletimizin devamı mümkün değildir." (Yeşilçayır, 2013, s. 37) diyerek benzer koşullanmanın içine girmiştir.

\section{Halkın Savaş Karşısındaki Tavrı}

İncelediğimiz romanların tamamında, muhasara yaklaştıkça Osmanlı toplumunda bir fikir ve gönül birliği oluştuğunu müşahede etmekteyiz. Edirne'de, bütün Trakya'da ve Anadolu'nun tamamında halkın fetih fikrine sıcak baktığını, Anadolu'daki Bektaşilerin, Horasan erenlerinin, bütün meslek gruplarının, çiftçilerin aynı heyecan ve istekle tek vücut olduğu görmekteyiz. Halkın fethe karşı geliştirdiği olumlu tavır, romanlarda kimi zaman ikincil derecede kahramanlarla verilmiş, kimi romanlarda ise bizzat roman kahramanı olan ve fakat tarihsel bir karşıllı̆g olmayan kahramanlar vasıtasıyla bu düşünce işlenmiştir. Mesela Fatih Feneri'nde romanın başkişisi Mustafa Bey'in şahsında somutlaşan bir Osmanlı tasviri yapılmıştır. Aynı sembolik yükleme romanın diğer kahramanlarından Kılıç Abdal ve Çopur Ali karakterlerine de yapılmıştır. 23 Mart 1453 günü Sultan Mehmet'in ordusu Edirne'den çıkış yapmış, her nefer ağır ve vakur bir eda ile yürüyüşe geçmiştir. Halk ordunu geçeceği istikamette yolları tutmuş, sevgi ve heyecan 
içinde aslanların hareketini izlemektedir. Ordunun şehirden tamamen çıkması tam iki saat sürmüş, buna rağmen halktan kimse oturmak ve dinlenmek ihtiyacı duymamıştır. Herkes, her birinde ayrı bir renk, ayrı bir zenginlik ve ayrı bir kuvvet bulunan Anadolu askerlerini görmek, doya doya seyretmek için can atmaktadır (Kozanoğlu, 1952, s. 139).

Muhasaraya destek anlamında halk tam anlamıyla ittifak içindeyken Edirne sarayında tam bir ihtilaf söz konusudur. İncelediğimiz romanların neredeyse tamamında Zağanos Paşa'nın başına çektiği bir grup şahince bir tavır içinde iken, ordunun belli bir bölümünün yüzyıllardır desteğini arkasına almış olan Çandarlı Halil Paşa'nın tek başına muhasaraya karşı olduğunu, en azından çekimser kaldığını görmekteyiz. Akşemsettin'in de belli romanlarda Sultan Mehmet'in yanında yer alan muhasara yanlısı yeni paşalara destek verdiğini belirtmeliyiz.

Romanlarda Edirne sade bir başkenttir. Şehir, coğrafi, mimarî ve tarihî hususiyetleriyle hiç öne çıkmamış, yaşayan, canlı bir şehir olmaktan ziyade, yalnızca buradaki Osmanlı sarayına ev sahipliği yapan bir yerleşim merkezi olarak karşımıza çıkmaktadır. Edirne'den tafsilatlı biçimde bahseden tek roman İstanbul Düşerken'dir. Romanda Edirne her ne kadar mamur bir başkent olarak tanıtılsa da o yine de fetih hazırlıklarına ev sahipliği yapan bir tür askerî karargâhtır:

Edirne, bir süre sonra başkent olmanın önemini kaybedeceğinden habersiz, köprüleriyle, camileriyle, saraylarıyla görenlere iç geçirtmekteydi... Kıbleye dönük odaları olan evleri ise Osmanlı'nın kimliğiyle bütünleşmiş İslam anlayışının en güzel tasvirleriydi. Ve şimdi

o güzelim kentte Osmanlı'nın kurmayları Bizans'a vuracakları son darbe için hazırlanıyorlardı. (Latif, 2008, s. 26).

Romana göre bu şehirde yaşayan halkın tümü, Moğollar devrini büyüklerinden dinlemiş, beylikler devrini yaşamış, Timur devrini görmüş kişilerden oluşmaktadır. Dolayısıyla birçok acılar ve sıkıntılar içinde pişmiş olan bu halk, iyiyi ve kötüyü ayırt edebilen bir toplum haline gelebilmiştir. Mensup oldukları dini, Asya'da ve Türkistan'da Müslüman olmuş dedelerinden daha iyi anlayan ve yaşayan bir yeterlilik içindedirler.

\section{Sosyo-Kültürel Dinamikler}

İncelediğimiz romanlarda Osmanlı adalet sistemi ve sosyo-ekonomik yapısı üzerinde etraflıca durulmadığını gözlemledik. Bunda, hali hazırda kâmil bir toplum kabulünün etkisi olmalıdır ve bu toplum her şeyi hak ettiği gibi İstanbul'u da fethedecektir. Buna karşılık Bizans halkı İstanbul'a layık değildir. Dolayısıyla incelediğimiz romanların ekseriyetinde Bizans'ın siyasi, sosyal, ekonomik, adlî ve idari yapısına olumsuz bir tavır geliştirilmiştir, romanlarda uzun uzun bu konular işlenmiştir. Tarihin Dönüm Noktası: Fatih Sultan Mehmet romanında idealize edilmiş bir Osmanlı toplumu vardır. Kavgadan, gürültüden uzak olan Osmanlılar, "dinlerinden aldıkları terbiye" icabı aşağılık şeylere tenezzül etmezler. (Subaşı, 2013, s. 111). Bir uzlaşmazlık veya kavga olduğunda, ilk işleri karşısındakini mahkemeye davet etmektir. Kadının verdiği hükme itaat etmek ise inancın bir gereğidir. Hatta kadının verdiği hükmün doğru olmadığını düşünerek bir başka kadıya gitmek veya davayı Divan-1 Hümayun'a götürmek bile mümkündür (Subaşı, 2013, s. 112)

Müjdelenen Komutan: Fatih Sultan Mehmet Han romaninda anlatılan bir anekdot, hem Fetih öncesi Osmanlı toplumunda ticari yapının ne derece yüksek olduğunu göstermesi bakımından, 
hem de ahi teşkilatının bu yapının oluşmasındaki rolünü göstermesi bakımından oldukça dikkat çekicidir. ${ }^{4}$ Romanda Ahi Evran'ın attığı temellerin ne kadar sağlam olduğu gerçeğinin altı çizilerek, ülkeyi bahtlı ve tahtlı yapan bu ruh zenginliği öne çıkarılmıştır.

Romanlarda Türkler mert insanlardır. Bu hakkı Bizans dahi teslim etmektedir. Fatih Sultan Mehmet-II romanında Ulubatlı Hasan, Şehzade Orhan'ın yanına casus olarak gönderilmiş bir cengâverdir. Sarayda, Bizans muhafızlarıyla kavgaya tutuşur. Hasan, burada adeta kükremiş bir aslan gibidir. Onun kısa sürede iki muhafızı etkisiz hâle getirişini İmparator Konstantin ve Şehzade Orhan da şahit olur. Şehzade Orhan yanındakine “Bu delikanlının mert ve asil bir çehresi var. Bu yağız renk, bu mağrur duruş ancak Türklere mahsustur." (Danışman, 1970, s. 7) demekten kendini alamaz. Olup biteni seyredenlerden biri de Notaras'ın kızıdır. Çehresiyle meydan okuyan Hasan'ı garip bir heyecanla süzen kız: “Yarabbim!.. Bu Türklerin hepsi mi böyle acaba? Ne kadar da mert, ne kadar da yiğit bir adam!" (Danışman, 1970, s. 8) diye kendi kendine söylenir. Anlatıcı, mertlik ve cesaret gibi iki yüksek hasleti, Bizans sarayında İmparatora ve baş vezirin kızına tasdik ve ikrar ettirerek Türkleri yüceltir.

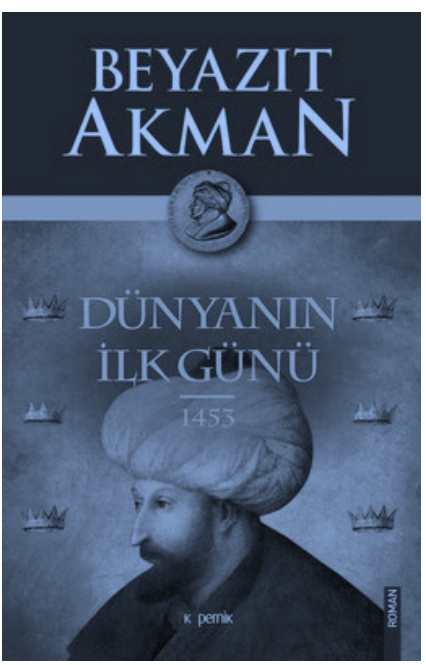

Dünyanın İlk Günü romanında Türklerin ilme verdikleri önem dile getirilmiştir. Kahraman-anlatıcı İtalyan Alberti, gizli bir hayranlıkla bağlı olduğu Nilüfer'le girdiği bir diyalogda Bizans halkının aksine "Türklerin yazı yazmayı ilahi bir görev gibi gördüğ̈̈" tesbitinden hareketle, "Türklerin üzerinde yazı olan bir kâğıt parçasını yere atmadıkları gibi, böyle bir kâğıt bulduklarında da yerden alıp yukarı bir yere koyduklarını" (Akman, 2012: 413) söyler. Romanda bir seyyah olan ve günlükleriyle fethe 1şı tutan Alberti, buradaki gözlemleriyle Bizans halkı ile Osmanlı halkı arasındaki entelektüel uçuruma dikkat çekmiştir.

Bizans toplumunda kilise ile cemaat arasında her anlamda bir kopukluk vardır. Aynı romanda İtalyan gezgin Alberti, bir tesadüfle tanışıp âşık olduğu Osmanlı kızı Nilüfer'e Hristiyan dünyasının içine düştüğü bu açmazı anlatırken, aynı zamanda Müslüman Osmanlı ile Hristiyan Bizans arasında bir mukayese yapmaktadır: “Bizde dini metinler sadece rahiplerin tekelinde, onları kafalarına göre yorumlayıp, cahil kitleleri de kendi çıkarlarına göre yönetirlerken burada bireyler kitapları kendileri okuyup ona göre hareket ediyorlar." (Akman, 2012, s. 414) demektedir.

\footnotetext{
${ }^{4}$ Menkıbeye göre “II. Mehmet, fetih hazırlıkları yaparken halkının durumunu yakından görmek ister. Edirne'nin çarşılarını gezmeye başlar. Sokağın başında bir dükkâna girer. Selam verdikten sonra:

-Bana yarım batman yağ, yarım batman bal ve biraz da peynir verin, der.

Müşterisini güler yüzle karşılayan esnaf, dikkatle yarım batman yağı tartar. Karşısındakinin padişah olduğundan bîhaber:

-Ağam, dilerseniz bal ve peynir de sarabilirim. Ancak ben yağı satarak siftahımı yaptım. Diğer isteklerinizi de henüz siftahını yapmayan karşı komşumdan alırsanız memnun olurum, der.

Padişah, esnafın tavrından memnun olur. Karşı dükkândan da, yarım batman bal ve biraz peynir ister. Yarım batman balı, aynı dikkat ve nezaket ile hazırlayan esnaf:

-Allah'a şükür siftahımızı yaptık. Peyniri de yan komşumdan alırsanız memnun olurum, der.

Sultan Mehmet, diğer dükkândan da peyniri aldıktan sonra:

-Bu millette, bu yüksek ahlak varken, değil yalnız İstanbul, dünya alınır, diyerek çarşıdan mutlu bir şekilde ayrılır"
} 
Fetih öncesi Osmanlı toplumunda, hoşgörü temelli bir inanç dünyası vardır. Kuşatma-1453 romanında, muhasaranın belli dönemlerinde silah ve ateş seslerinin sustuğu bir anda Bizanslılar'ı şaşkınlığa sürükleyen bir gelişme olmuştur. Osmanlı ordusu içinde Hristiyan unsurların dini ayinlerinden yükselen sesler, Bizanslıların kulaklarına kadar ulaşmıştır. Bu, Osmanlı'nın azınlıklara -çağına göre- olağanüstü bir dinî hoşgörü uyguladığının kanıtıdır. Oysa Roma'nın hâkim olduğu topraklarda halkların dinlerini, dillerini, isimlerini değiştirerek asimile edici bir politika izlediği gerçeği, 1204'teki Katolik zulmünün izlerini hafızalarından henüz silememiş bir halk için ürperti verici olmuştur. Osmanlı'nın hoşgörülü tavrı, Bizans halkı üzerinde olumlu bir etki bırakmıştır ve İmparator, bu tesiri fark eder etmez, bütün bunların bir gösteri olduğu şayiasını çıkarmıştır. Ancak halk İmparatoru ürkütecek kadar işittiklerinin tesirinde kalmıştır (Tiryakioğlu, 2009, s. 82).

\section{FETİH ÖNCESİ BİZANS - HRISTTIYAN DÜNYASI}

\subsection{Siyasi ve Genel Durum}

İstanbul, antik çağlardan beri çeşitli milletlerin ve İslam dünyasının sürekli ilgi odağı olmuş, tarih boyunca kuşatmalara maruz kalmış bir şehirdir. Ancak yapılan bütün kuşatmalara rağmen hiçbir devlet İstanbul'u elde etme hayalini gerçekleştirememiştir. İncelediğimiz romanların bir bölümünde bu konuya da değinilmiştir. Böylelikle fethin güçlüğü öne çıkarılmış, başarılması ne denli zor bir iş olduğu vurgulanmıştır. Dolayısıyla bunu başaran hükümdarın ve ordunun yüceltilecek muvaffakiyeti için zemin hazırlanmıştır.

Aslına bakılırsa sadece II. Mehmet değil, babası II Murat, Şehzade Musa Çelebi, Güzelce Hisar'ı yaptıran dedesinin babası Yıldırım Beyazıd da şehri kuşatmıştı. Onlardan çok önce Konstantinopolis'e saldıran Acemleri, Arapları, Vikingleri, Hunları, Gotları saymıyorum bile. Bütün bu halklar içinde Osmanlılardan önce şehre sadece Latinler girebilmişti, 1204 yılında. (Ümit, 2012, s. 261).

Çalışmamıza konu olan romanlarda fetih öncesi İstanbul tasvirleri genellikle olumsuz bir bakış açısıyla ele alınmıştır. İstanbul'un fiziki ve psikolojik tasvirleri son derece iç karartıcı bir mahiyettedir. Bu söylem, adeta okuyucuyu fethe razı etme aracıdır. Tespitlerimizin istisnası olacak bir roman 1453'tür. Romanda Konstantinos öyle bir memlekettir ki:

Geniş geniş yollarında at arabaları türlü sebze ve meyve taşımaktadır. Her köşe başında bir çeşme akmaktadır. Birbirinden güzel giyimli ve alımlı kadınlar çarşılarında alışveriş yapmaktadır. Bembeyaz mermerler, seramikten heykeller, dükkânların önünü süslemektedir. Şehirde güzel bir koku vardır. Sokakların arasında rüzgârların taşıdığı bu koku, insanların evlerinin önünde yetiştirdiği çiçeklerin kokusudur. Hüzünlü bir mutluluk kaplıdır şehirde adeta. Evlerin çoğu ahşap, dükkânlar ise kâgirdi ve beyaz boyalıydı, şehirde beyazın bariz bir hâkimiyeti vardı. (Çalık, 2012, s. 66).

Derken, huzur ve şaşaa dolu günler sona erer. Aziz Sofi romanında Ayasofya dört gözle Sultan Mehmet'i ve askerlerini bekleyen bir roman kahramanıdır. Onun gözünden Türklerin İstanbul'a yaklaşmaları, şehri nasıl yıl yıl çembere aldıkları ve bunun sonucunda oluşan BizansOsmanlı siyasi ilişkileri şöyle anlatılır:

Bu yeni ortaya çıkan millet, daha doğrusu benim yeni ve ilk kez gördüğüm bu millet, öyle çekip gideceğe benzemiyordu. Gelip İstanbul'un çevresine yerleşmişlerdi ve hiç de 
bırakıp gitmeye niyetleri yoktu. Bizanslılar adım adım İstanbul surlarına yaklaşan, lokma lokma ülkelerini yutan bu milletten tanrıya sığınıyorlardı. Belki de gözleri korkmuştu bu milletten ve ona karşı koyamayacaklarından olacak ki, sık sık bana gelip dualar ediyorlardı... Sonra gelip Üsküdar'a yerleştiler. Zaten daha önce Rumeli'ye yerleşmişler ve Edirne'yi hükumet merkezi yapmışlardı. Bizanslılar onlara korku ve hayranlıkla bakıyorlardı. Bazen dostluk çabaları fayda etmiyor, bu millet İstanbul'u muhasara ediveriyordu. İmparator elçiler gönderip hediyeler yollayarak onlardan şehrini kurtariyordu. (Yılmaz, 1976, s. 82).

Çemberin daralmaya başladığı günlerde Bizans sarayı gaflet içindedir. Bizans'ın Son Günleri romanına göre, yaklaşan tehlikenin farkında olanlar, yalnızca kimi halk sanatçılarının başını çektiği aydınlardır. Şehrin geniş alanlarında yapılan halk toplantıları, zamanla bir ihtilal hareketine dönüşmüştür. Konstantin'in zevk ve neşe içinde, genç ve güzel kadınları başına toplamış şekilde eğlendiği bir günde ihtilalciler sarayın etrafını kuşatır. Bu esnada:

Sarayın iç bahçesinde büyük havuzun içindeki köşkte, Konstantin, çiçeklerle donatılmış muhteşem ve zarif bir taht üzerinde oturmaktadır. Yanında veziri Notaras ve Elvira, imparatora şarap ikram etmektedir... Havuzun içinde, su üzerinde yüzen büyük kaplumbağaların sırtlarına dikilmiş olan yeşil, kırmızı, mavi renkli mumların su üstüne akseden ışıkları arasında çıplak kadınların raks ettikleri görülmekte ve çam ağaçlarının ardından akseden hazin gitara ve mandolin sedaları, gözleri ve beyinleri dumanlanan saraylıları büsbütün coşturmaktadır. (Sertelli, 1930, s. 105).

Halkın sarayın etrafını sardığı haberi geldiğinde, İmparator'un tepkisi "Saf ve bana sadık tebaamın fikir ve rahatını bozmasınlar" (Sertelli, 1930, s. 106) şeklinde olmuştur. İmparator, bütün yazı Vlaherna Sarayı'ndaki dairesinin taraçasından denizi gözleyerek geçirir (Altınyelekoğlu, 2012, s. 601).

Sarayın vurdumduymazlığı, mahalli kurtuluş örgütlenmelerine neden olmuştur. Fatih Feneri romanında bu türden yapılanmalara yer verilir. Halk, bir muhasara olursa, şehrin nasıl savunulacağı hususunda kafa yormakta, planlar yapmaktadır. Fakat burada da bir başıbozukluk dikkat çekmektedir. Bu kez de Hristiyan toplum içindeki her etnik ve dini yapı, kurulacak askeri teşkilatın başında kendilerinden bir kumandan olması gerektiğinde ısrarcı olur: "Kimse kimsenin nüfuzunu kabul etmiyor, her biri kendi arzusunda israr ediyordu. Her köşe başında bir serseri karşısına aldığı beş on kopuğa şehrin yalnız kendisi tarafından müdafaa edilebileceğini ispat etmek için planlarını anlatmaya çalışıyordu." (Kozonoğlu, 1952, s. 104). İmparator nihayet yaklaşan tehlikenin farkına varmıştır: "Konstantin, ayağa kalktı. Duvardaki eski Bizans haritasının önünde durdu. Düşünüyordu. Ecdadının hükmettiği yerlerin beşte dördü kaybolmuştu. Bizans İmparatorluğu şimdi ufak bir vilayet hâlinde kalmıştı." (Sertelli, 1930, s. 112).

Hemen bütün romanda, muhasara öncesi Bizans'taki yerleşim alanlarından, nüfusundan, asker sayısından bahsedilmiş, kimi romanlarda yazarlar bu bilgileri dipnotlar vererek tarihi verilerle desteklemişlerdir. Buna göre Bizans sadece bir vilayet halinde kalmamış, ahalisi de azalmıştır. Bizans surları haricindeki köyler müstesna olmak üzere, sur dâhilinde elli-elli beş binden fazla nüfus yoktur. Şu durumda surlara yerleştirilebilecek asker sayısı beş bini geçmeyecektir. Yeni ve tehlikeli bir vaziyet karşısında, belki iki bin asker daha toplayabilecektir. “Konstantin o sabah ilk defa olarak, hissiyatına hâkim bir kumandan düşüncesiyle hareket etmeye 
ve tehlikeyi yakından görmeye başlamıştır." (Sertelli, 1930, s. 113) Özellikle Osmanlı'nın yanı başlarında bir kale diktiğini duyduktan beri İmparator da halk da iyiden iyiye korku içindedir. "Yaşlıların utanarak, gençlerin isyanın eşiğinde gezindiği günlerin birinde İmparator'un şöyle söylendiği duyulmuştur: Gençler haklı, Malazgirt felaketinden bu yana yiyip bitirdik koca imparatorluğu." (Altınyelekoğlu, 2012, s. 602) Yine bir gün Bizans İmparatoru çaresizliğin pençesinde kıvranırken birtakım halüsinasyonlar görmeye başlar:

Acaba Türk orduları surlardan içeri girmişler midir? Şimdi saraya doğru mu geliyorlardı!.. Bir an bütün varlığını müthiş bir korku kapladı. Gözleri yerinden oynamıştı. Damarlarındaki bütün kan çekiliyordu. Dizlerinde derman kalmamıştı. Bir eliyle duvara dayanarak yavaş yavaş sedire çöktü. Elleriyle yüzünü kapadı. Konstantin ağliyordu (Danışman, 1970, s. 52).

Osmanlı sultanının gittikçe artan faaliyetleri, aklı başında olan bütün Bizans ricalini şüphe içinde kıvrandırmaya yetmiştir: “Vakıa Bizanslılar, yüz elli seneden beri birçok defalar Türk padişahlarının tazyikine uğramışlardır. Fakat siyasi entrikalarla bu tazyikler önlenebilmiştir. Fakat bu defaki, daha evvelkilere hiç benzemiyordu (Danışman, 1970, s. 69).

"Siyasi entrika" meselesi pek çok romanda işlenmiştir. Halkın önemli bir kısmı boş ve manasız birtakım itikatlara bağlanmışsa da Bizans'ta memleketin akıbetini yakından gören münevver bir zümre de vardır. İmparator ve Veziri Notaras, romanlarda bu zümre ile sıkça müzakere halindedir. Müzakere meclislerinde her zaman din adamları da bulunmaktadır. Bazı romanlarda bu meclise dışardan Katolik din adamları da iştirak eder, katkıda bulunurlar. Bu meclislerden genellikle Türklerle uyuşma, anlaşma neticesi çıkar, o da olmazsa Bizans'ı müdafaa etmek, bunun için de surları tamir etmek fikri üzerinde durulur.

\subsection{Sosyo-Ekonomik Yap1}

Çalışmamıza konu olan romanların neredeyse tamamı Bizans toplumunun sosyal, ekonomik ve psikolojik yapısı üzerinde tafsilatlı bilgi içermektedir. Aynı konular Osmanlı toplumu için ayrıntılı biçimde mevzu edilmezken, Bizans söz konusu olduğunda tavır değişmektedir.

1453-Surların Altından: Fatih'in Çocukları romanında diğer romanların aksine Bizans'ta çarşıpazar tasvirleri olumlu bir bakış açısıyla yapılmıştır.

Bizans'ın her bucağı bir arı kovanına benziyordu, her sokak bir pazardı. Her semtte birçok alışveriş yapılıyor, halk sanki harp yokmuş gibi neşeyle ümit içinde dolaşıyordu. Surlarda askerler Türklerle çarpışırken, çarşılarda ve pazarlarda içki, hayvan, güzel koku, güzel kadın, elmas, ipekli kumaş, kadın, halı... Yani saltanat ve sefahati tamamlayacak her şey serbestçe satılıyordu. Sokaklarda binbir ırktan binbir kişi dolanıyordu. Batıdan, Doğudan, uzak Şarktan ve birçok diyardan Bizans'a alışveriş için akın ediliyordu (Sertelli, 1930, s. 307).

Romana göre Bizans'ta siyasi ve askeri işler yolunda gitmezken, sokaklar bundan hiç etkilenmemiş görünmektedir. Halk günlük hayatına alışılageldiği gibi devam etmekte, çarşı-Pazar cıvıl cıvıl, alışveriş edenlerle dolup taşmaktadır. Şehirdeki yabancılar, belki de muhasaranın püskürtüleceğinden emin, şehirden uzaklaşmayı düşünmemişlerdir.

Fetih öncesi ve esnasında Bizans toplum yapısı, diğer romanlarda trajik bir bakış açısıyla işlenmiştir. Açlık ve sefalet şehrin sokaklarını adeta esir almıştır: “Bizans tarihin en karanlık 
çağlarından birini yaşıyor, Konstantiniye'de insanlar yeterince sağlık hizmeti görmek bir yana, kâfi miktarda su bile içemiyorlardı. Bu mübarek şehirde salgın hastalıklar, kir ve pislik kol geziyordu. Kimsenin kimseye ne bir merhameti ne bir itimadı kalmıştı. Hırsızlık ve yolsuzluk alabildiğine yaygınlaşmıştı." (Subaşı, 2013, s. 22) İstanbul'un içine düştüğü sefaleti en çok öne çıkaran romanlardan biri de Kara Büyülü Uyku'dur.

Hüzünlü kent, ölüm döşeğinde son zamanlarını yaşayan ağır bir hastayı andırıyordu; surların arkasındaki bostanlar ve asma bahçeleri bakımsızlıktan harap durumdaydı. Evlerin çoğu yıkılmak üzereydiler. Kentin yollarında öbek öbek toz ve pislik yığınları görülüyordu. Uyuz kedi ve köpekler bu pisliklerin üzerine sırtüstü yatıp kaşınıyorlardı. Her köşe başı dilenciler tarafından tutulmuştu (Çıracıoğlu, 1999, s. 35).

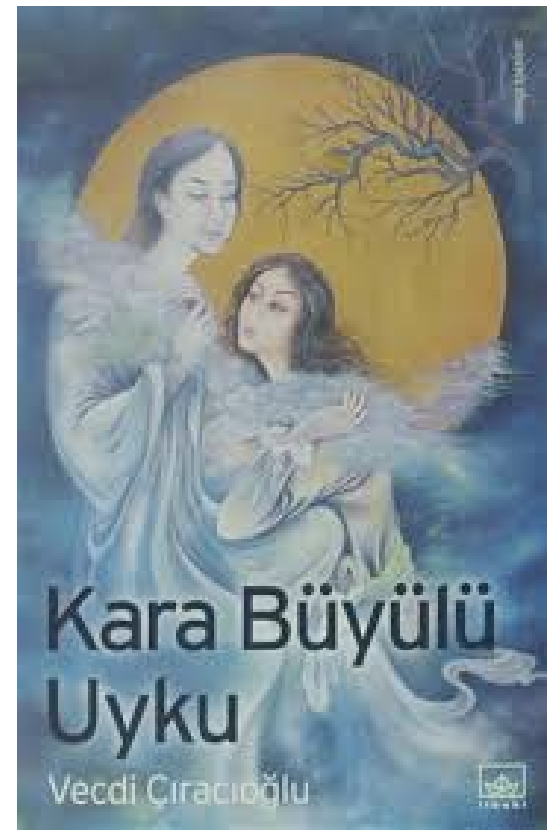

Romana göre dilenciler, aç insanlar, uyuz sokak hayvanları, bakımsız surları ve yer yer dökülen yapılarıyla Konstantin, ağır ağır yaklaşmakta olan ölümü bekleyen bir canlı gibidir. Zenginler ve soylular, takılarını ve değerli mallarını yanlarına alarak kenti terk etmişlerdir. Geride yalnızca maceraperestler, casuslar, hırsızlar ve kendilerinin gerçek Romalı olduğunu iddia eden az sayıda soylu ile imparatorun ailesi ve yakınları kalmıştır (Çıracıoğlu: 36).

Hüzün ve çaresizliğin iyiden iyiye çöktüğü şehirde, Patrik pazar günleri Ayasofya'nın kubbesi altında toplanmış halka öte dünyadan umutlar dağıtmaktadır. Kardeşlikten, yardımlaşmadan ve imandan bahseden bu nutuklara, aç ve yorgun insanlar kulaklarını çoktan kapamıştır (Yılmaz: 87). Kentin kalbi sayılan Ayasofya, yoksulların ve dilencilerin barınağıydı artık ve günlerdir dışarıdan yardım alamayan halk aç, yorgun ve perişandır (Çıracıoğlu: 36). Bizans İmparatorluğu her bakımdan en zor günlerini yaşamaktadır.

Rum Ateşi, Prenses İrena'yı merkeze koyan ve dolayısıyla sarayı dar-kapalı mekân olarak alan bir romandır. Romanda İmparatorun ve vezirin makam odaları, sarayın geniş koridorları, dev eğlence salonları, hamamlar, bakımlı ve yemyeşil bahçeleri ayrıntılı biçimde işlenmiştir. Şehrin sokaklarında halk açlık içinde kıvranırken, sarayda bir lüks ve şaşaa hâkimdir:

Başvekil Lukas Notaras'ın salonu, İmparator'un özel odasından daha süslü idi. Yerlere altın kakmalı mozaikler işlenmiş, pencerelere Hint kumaşından sırmalı perdeler asılmıştı. Tam orta yerdeki altın yaldızlı fildişi masanın üzerinde mevsim meyveleri konmuş, ayrıca altın kâselere de kuru yemişler doldurulmuştu. Salonun her köşesinde sarı burma ayaklı altın kollu şamdanlar vardı. Tavandaki renkli resimler göz alıyordu (Alpar, 1966, s. 17).

Sarayda israf ve konfor bu derece üst seviyede iken hazinenin durumu kimsenin umurunda değildir. Bir topçu ustası bile doyurulamamaktadır (Alpar, 1966, s. 36). “İmparator her ne kadar soyluların ve kendisinin değerli takılarını eriterek paraya çevirmiş ise de hazine açı̆̆ını kapatamıyordu. Gedik büyüktü ve yama tutmuyordu. Bastırılan paralar, dışarıdan getirilen un, yağ ve şaraba gidiyordu. Mahzenleri zamanında ağzına kadar şarap ve yiyecekle dolup taşan zümrüt kent şimdi açlıktan kırılıyordu." (Çıracıoğlu: 36). 
Bütün bunlar yetmezmiş gibi Bizans halkının omuzlarına ağır vergiler de yüklenmiştir. Tüm gelir kaynaklarını yitirmiş olan saray, ister istemez ağzını bir hortum gibi bu aç insanların boş midelerine uzatmıştı. (Yılmaz: 88) Hatta öyle ki, kiliselerdeki mukaddes eşyalar pazarlarda satılıyor, para kalmayınca halktan yine zorla vergi alınıyordu (Şopolya, 1953, s. 59).

\subsection{Bizans'ta Ahlaki Yap1}

Tezimize malzeme olan romanların tamaminda, kimisinde kısa, kimisinde ayrıntılı bir biçimde Bizans toplumunun ahlaki yapısından kesitler verilmiştir. Ahlaken tefessüh etmiş bir toplumun artık bu güzelim şehri hak etmediği ve bunun doğal sonucu olarak, Orta Asya'dan gelen bir kavmin şehri ele geçirişi gözler önüne serilmiştir. Bunun da Tanrı'nın koyduğu yasalara uygun bir işleyiş olduğu fikri, sürekli ve sistematik olarak okuyucunun zihnine işlenmiştir. Romanlardaki bakış açılarında bu konuda bir farklılık yoktur. Sepetçioğlu'nun “Fetih Üçlemesi"nin son kitabı olan Gece Vaktinde Gündönümüَ romanında toplumsal manzara şöyle tasvir edilmiştir:

(İstanbul'da) limanlar it, kopuk, hayta, işsiz ve ayak takımıyla dolu[ydu]. Gencecik yaşta sokağa dökülmüş bacağı açıkta kadınlar, acemi, yarı acemi, çaylak, itleşmiş, kancık köpek kaynaşmasında ısıracak adam arar kadınlar... Sonra düşkünler, sonra iki yakası hiçbir vakit bir araya gelememişler... Sonra..? Bizans idi bre bunun burası, biri bitse ulanıp öteki başlayacak. (Sepetçioğlu, 1993, s. 202)

Aynı bakış açısıyla pek çok romanda karşılaşmak mümkündür. İstanbul'un fethini direkt olarak işlemese de olayları İstanbul'un fethine kadar götüren ilk romanlardan olan Süleyman Musli6'de anlatıcı, Musul ve Kudüs dolaylarında yaşayan roman kahramanı Süleyman'ı Haşhaşîler'in reisi Şeyhü'l-Cebel'in sevgilisi olan, ancak Bizans İmparatoru Roberdi Kortney'in karısı bulunan Margarit'i kaçırmak üzere İstanbul'a göndertir (Doğanay, 1998, s. 34). Bu vesileyle de İstanbul'dan ve tarihinden söz açılır. Anlatıcı Latinlerin 1204'de şehri istila ettiğini belirterek, sözü İstanbul'un fethine getirir ve İstanbul'un Fatih Sultan Mehmet tarafından fethedilmesiyle şehirde mimari olarak çok büyük olumlu değişiklikler olduğunu belirtir. Yani, 1243'de İstanbul'a giren Haçlılar ile 1453'de giren Türkler arasında mukayeseler yaparak ikincisin üstün görür ve medeniyete hizmet ettiğinin söyler (Uğurcan, 1995, s. 557). Ardından okuyucuya şöyle bir soru sorar: “Acaba Rum İmparatorluğu'nun Latin İmparatorluğu'na tahavvülü esnasında dahi böyle bir intizam ve inzibat hâsıl olup olmadığı şu aralık hatırınıza hutûr eder mi?" (Ahmet Mithat, 2000, s. 137) Anlatıcı tam bu noktada iki dönem arasında kıyasa girmeden önce, fetihten önce Bizans'1n ahlaken ne kadar düşkün olduğu hususunda bilgiler verir:

... isti'dad-ı zamanın gösterdiği imkân mertebesinde medeniyeti terakkî ederek o zamanın mertebe-i kemâline varmış ve fakat... ahlak ve adât şimdilerde hemen hemen tasavvur bile edemeyeceğimiz derecede bozulmuş idi. Bir hazineye bir kuşluk taamı etmek ve bir aşüftenin fuhşu yolunda cihanı

\footnotetext{
${ }^{5}$ Argunşah'a göre (1990) romanın isminde yer alan “gece” Bizans'ın içinde bulunduğu çöküntüyü ifade etmektedir..

${ }^{6}$ Her ne kadar Zeki Taştan, Kazım Yetiş'in editörlüğünde yayımladıkları Türk Edebiyâtında İstanbul'un Fethi ve Fatih çalışmasında, Türk edebiyâtında Fatih Sultan Mehmet devrine giden ilk roman olarak Süleyman Sudî tarafından I. Dünya Savaşı yıllarında neşredilen Kızıl Köşk'ü göstermişse de, bizim yaptı̆̆ımız çalışmada söz konusu romandan önce İstanbul'un fethine temas eden iki romana daha ulaşılmıştır. Bunlar Ahmet Mithat Efendi'nin Hüseyin Fellah (1875) ve Süleyman Muslî (1877) adlı romanlarıdır.
} 
feda eylemek, zevciyyet ve sihriyyet büsbütün muzmahil olmak Roma'nın şu mertebe-i kemâlinde görülmüş ahvâldendir (Ahmet Mithat: 138).

Anlatıcıya göre Bizans'ta ahlaksızlık, romanın yazıldığı devir için bile tasavvur edemeyeceğimiz ölçüde almış yürümüştür. Bir hazineye bir kuşluk taamı edilmekte, bir aşüftenin fuhşu yolunda âdeta cihan fedâ edilmektedir. Nikâhsız yaşamak son derece yaygındır, aile diye bir müessese kalmamıştır. Durum, bu kadar vahimdir. Romanın ilerleyen bölümlerinde yeniden tarihsel bir yolculuğa çıkılmış, Roma'nın Doğu ve Batı diye ikiye ayrılmasından söz edilerek yeniden Doğu Roma'ya gelinmiştir. Burası, yani İstanbul, Roma İmparatorluğu'nun bölünmesinden önce de son derece büyük bir çöküntü içindedir. Bölünmeden sonra her ne kadar, Anadolu tarafından Araplar ve Türkler, Rumeli tarafından Bulgarlar ve sair kabileler burayı almak istemişse de alamamışlardır. Adı geçen bu kavimler bedevîlikten gelen güzel ahlaklarını etrafa yaymışlar ancak İstanbul'a etki edememişlerdir. İstanbul'da da yani Doğu Roma'da da ahlaksızlık son sınırındadır: "Sevdalısını imparatorluk makamına kadar is'ad için kocasına kasd eden İmparatoriçeler mi istersiniz? Kezâlik müntehabını bu belâlı mevki'e çıkarmak için o mevki'in varisi kendi ciğerparesi evladını kurban eden imparatoriçe valideleri mi istersiniz? Zevcesine malik olmak için karındaşına kasd eden birader mi istersiniz? Hâsılı hayal ve tasavvura bile sığmayacak bir hâl ki maâzallah." (Ahmet Mithat: 139).

Anlatıcıya göre, şehvet ve hırs yalnızca sokaktaki sade vatandaşı esir almamış, ahlaksızlığın en âlâsı saraya dahi girmiştir. Nitekim kraliçeler, gizli aşklarının sarayda yükselebilmeleri için gerektiğinde kocalarına kıyabilmekte, hatta evlatlarını kurban etmektedirler. Zevcesine sahip olabilmek için kardeşini öldürenler ve niceleri... Hasılı, Bizans hiçbir hayal ve düşünceye sığamayacak bir batağın içindedir.

Bizanslılar kadına ve güzele hayrandır; onlar için her şey kadın, zevk, sefahat ve eğlenceden ibarettir (Danışman, 1970, s. 164). Şehrin sokaklarını esir alan şehvet, sadist mazoşist davranışlara dönüşmüştür: “Son günlerde güzel kadınlar sokağa çıkacakları zaman eski elbiseler giyiyor, çirkin görünmek için yüzlerine çamur sürüyorlardı. Çünkü güzel kadınlara taarruz ediliyordu. Sokaklar sarhoşlarla dolu idi. Erkekler şehvet anlarında kadınların çıplak vücutlarını kırbaçlarla dövüyor, bu vücut azabından kadınlar zevk alıyorlardı." (Şapolyo, 1953, s. 60).

Şehrin belli mekânları zengin ve soylular için birer fuhuş yuvasıdır. Konstantiniye'nin aç ve sefil uykuya daldığı gecelerde, zenginler kendileri için hazırlanan hamam sefalarına iştirak ederler. Baştanbaşa mermer kaplı salonlar, kıymettar heykeller, altın ibrik ve tabaklarla dolu gümüş masalarda yenen yemekler, küçüklü büyüklü havuzlara aslan ağılarından akan sular, bunların hepsi zenginlerin konforu içindir (Tepedenlioğlu, 1973, s. 65). Bu hamamlardan en meşhuru da Dalila isimli bir yabancı kadının işlettiği Bosforüs'tür. Bizanslıların çoğunun “aşk tapınağı" diye andığı bu hamamın dünyada eşi benzeri yoktur.

Dünyanın dört bir tarafından kopup gelen gemi kaptanları, zengin tüccarları bu aşk evine uğramadan gitmezlerdi. Galata Cenevizlilerinin altınları her akşam oluk oluk Bosforüs'e akardı. Bizans'ın fakir düşmüş asilleri de buraya uğrardı. Kadın, onlardan para beklemezdi, ama adlarından faydalanirdi. (Alpar, 1966, s. 34)

Ayrıca Bizans imparatorlarının kendileri için inşa ettirdikleri bir hamam vardır ki, orasının adı Vlakerna Hamamıdır. Şehirde giderek yaygınlaşan bir başka alışkanlık da kumardır. 
İmparator her ne kadar şehirde kumar oynamayı yasak etmişse de kimsenin dinlediği yoktur. Mor kadife elbiseler giymiş, yüzleri kadın gibi boyalı, kakülleri gözlerine dökülen genç oğlanlar isteyenlere şarap getirmektedir (Alpar, 1966, s. 134). Romanda bu şekilde Bizanslı zenginlerin eşcinsel eğilimleri olduğu ima edilmiştir.

Bizans halkı, haksızlıklarla birbirinin gözünü oyan ve (birbirinin) elindeki bir lokma ekmeğe göz diken insanlardır. (Tuğcu, 1972, s. 13) Aynı zamanda, ateşli, sıcakkanlı, dedikoduyu, eğlenceyi çok seven bir millettir Bizanslılar. En ufak bir olay büyüyor, dallanıyor, budaklanıyor, şehirde türlü söylentilere yol açıyordu (Alpar, 1966, s. 22).

Bizans, zenginin fakiri, güçlünün zayıfı sindirdiği, ezdiği bir toplumdur. Parası olanlar her şeye sahiptir. Ancak kendi hâlindeki insanların çocukları askere alınmaktadır (Tuğcu, 1972, s. 59).

Bizans toplumunda sosyal yapının bozulmasında adalet mekanizmasının çökmesi önemli rol oynamıştır. Ahlaksızlık ve adaletsizlik birlikte büyümüş, adeta birbirini besleyen unsurlar hâline gelmiş, adaletin çalışmadığı yerde iş başa düşmüştür: “Bir erkeğin yanında bulunan bir kadına yan gözle bakmasıyla birlikte yapılması gereken tek şey, düello ile karşısındakini öldürmektir. Bu kanunsuz ve yersiz hareketinden dolayı şiddetle alkışlanır ve nâmı yürür, ölene de bakılmazdı. Aynı kişi herhangi bir harpte bir kalenin surunu yıksa, belki de bu kadar rağbet görmezdi." (Subaşı: 111).

Yoksulluk, başını alıp giden adaletsizlik ve umutsuzluk zamanla Bizans halkını sokaklara dökmeye başlamıştır. Vatansever gençlerin başını çektiği gruplar, şehrin belli meydanlarını, özellikle de mabetlerin içini ve önünü doldurmaya başlamıştır. Gün geçtikçe dozu artan eylemler zamanla bir isyana dönüşmüştür. Sarayın isyanları bastırma konusunda aldığı tedbirler oldukça sert olmuştur: “Bu isyanlar ise pek kanlı olarak bastırılıyordu. Asilerin vücutları parça parça ediliyor, gözleri oyuluyordu. Bazen asilerin kesik başlarıyla içki masasında top oynuyorlar, sonra bu kanlı başı ailelerine gönderiyorlardı." (Şapolyo, 1953, s. 53).

İsyanları bastırmak için İmparator’un aldığı önlemlerden biri de hafiye teşkilatı kurmaktır. Toplum içinde ne kadar ahlaksız ve merhametsiz varsa, onlar önlerine geleni İmparator'a jurnal etmeye başlamıştır. Yakalananlar ise yargılanmaksızın vücutları şişe geçirilerek at meydanında bir ateşte cayır cayır yakılmaktadır (Şapolyo, 1953, s. 60). Hafiyeler yüzünden toplumda huzur kalmamış, kimsenin kimseye güvenmediği, herkesin tedirgin olduğu bir dönem başlamıştır. Hukukun tamamen ayaklar altına alındığı bu dönemde İmparator işlenen suçlara pek aldırmaz; büyük davaları, Bizans'ın kurtuluşundan sonraya bırakmaya başlamıştır. Belki de genel bir afla ortalığın temizlenmesi hesap edilmektedir (Tuğcu, 1972, s. 75).

\subsection{Yaklaşan Tehlike Karşısında Bizans Halkının Tavrı}

İstanbul'un fethini konu alan romanların bir kısmında Bizans halkının yaklaşan tehlikenin farkında olduğu görüyoruz. Diğerleri umursamaz biz tavır içindedir. Muhasara başladıktan sonra bile halkın bir kısmının şehrin savunulmasından yana olduğu, diğer kısmının ise şehri savaşmadan teslim etmekten yana olduğunu görüyoruz. Yine romanların pek çoğunda halkın umutsuz ve moralsiz olduğunu, korku ve çaresizlik içinde kaldığını görmekteyiz.

Zuhuri Danışman'ın romanında Bizans sokakları adeta bir nehir gibidir. İnsanlar birbirini ite kaka, güle oynaya sirke doğru gitmektedir. Herşey alışıla geldiği üzere kendi doğal mecrasında işlemektedir. İmparator da bu gidişattan son derece memnundur. Halk ve İmparator yakınlarında 
dolaşan tehlikenin hiç farkında değildir. Kimse geleceği düşünmemekte, herkes günü gününe yaşamaktadır. (Danışman, 1970, s. 5) Aynı eğlencelerden sarayda da yapılmaktadır. İmparatorun verdiği davetlerde içki su gibi akmakta, yarı üryan Bizans dilberleri süslü saray adamlarının kollarında dolaşmaktadır. (Danışman, 1970, s. 32) Bu davetlere ilgiyi en çok genç kızlar göstermektedir. Çünkü İmparator hâlâ bekârdır ve kiminle evleneceği belli değildir. Kızların içinde en şanslı olanı hiç kuşkusuz Başvekil Grandük Notaras'ın kızı İren' dir.7

Bizans'ta gaflet o kadar had safhadadır ki, İmparatorluk Meclisinde tartışılan konu "meleklerin kadın mı, erkek mi olduğu"dur. Günlerdir tartışmanın sürdügü konsülde geçici patrik ve diğer üst düzey din adamları, komutanlar, üst yöneticiler ve asiller hararetli bir şekilde bu konuyu müzakere etmektedirler (Latif, 2008, s. 70).

Sarayda işler bu şekilde yürürken, aynı umursamaz hava dışarıya da hâkimdir. Halk, heyecan ve eğlence dolu oyunların peşinde, hayatından gayet memnun bir vaziyettedir. $\mathrm{Bu}$ eğlencelerin en meşhuru "tyzkaninon" dur. ${ }^{8}$ Final müsabakalarının olduğu günlerde Konstantiniye hop oturup hop kalkmakta, kadınlar ve erkekler heyecan içerisinde hipodroma koşmakta, bu kapışmayı seyretmeye can atmaktadır (Altınyeleklioğlu, 2012, s. 190). Hâl böyle iken, Bizans'1 koruyacak ve uğrunda kanını dökecek insanlar pek azdır: “Yalnız yemek yemek, gülüp oynamak istiyorlardı. Her akşam içki âlemleri devam ediyor, akşamdan şarap içmeye başlıyorlar ve gece yarısı mideleri dolunca bir tüyü ağızlarına sokarak kusuyorlardı. Sonra tekrar sofralarına dönüyorlard1." (Şapolyo, 1953, s. 59).

Bizans'tan savaşa karşı olanlar ya savaştan kaçmakta ya da şehri terk etmektedir. Muhasaranın en hararetli yerinde, Latinler ve Cenevizliler, Bizans'ın müdafaası için canla başla savaşırken, şehrin asıl sahipleri olan Rumlardan birçokları, surlara koşup felakete göğüs germemek için türlü özürler ve bahanelerle ortadan savuşmaktadır. Ailelerinin himayelerini, kadınlarına ve çocuklarına yiyecek tedarikini bahane ederek evlerinde kalmayı tercih etmişlerdir. Bunu fark eden İmparator birçok tedbirlere girişir. Asker kaçaklarına, şiddetli cezalar tertip edilir. Birinci defada askerden kaçanlar, büyük meydanlarda ve halk arasında yüzüstü yere yatırılıyor, kamçı ile dövülüyordu. Aynı asker bir daha kaçacak olursa, idam ediliyordu (Şakir, 1940, s. 158).

Kalenin akıbetinden ümidini kesen pek çok kişi, paralarını saklamaya başlamıştır. Onların planı, bir karışıklık durumunda bir yerlere saklanmak ve sonra bir yolunu bulup kalenin dişına kaçmaktır. Şehirde kalanlar ise daha önce depo ettikleri yiyeceklerle geçiniyor, kendi hemşerilerine yardımdan kaçınıyorlardı (Tuğcu, 1972, s. 75).

Sokakta bütün bunlar olup biterken sarayda hararetli tartışmalar sürüp gitmekte, şehrin sahipleri yaklaşan tehlikenin nasıl bertaraf edileceği üzerinde çareler aramaktadır. Neredeyse bütün romanlarda bu husus üzerinde durulmaktadır. Bizans'ın neler yapabileceğinin, önündeki seçeneklerin neler olduğunun masaya yatırıldığı bu toplantılarda, Bizans'ın Osmanlılarla, Anadolu'daki beyliklerle ve diğer Hristiyan devletlerle ilişkilerine ait detaylar ortaya çıkmakta, adeta devrin bir siyasi panoraması oluşmaktadır:

\footnotetext{
7 İncelediğimiz romanların içinde çoğu kez İren, bazen İreni, bazen de Eleni ismiyle karşımıza çıkan bu genç kız, Zuhuri Danışman'ın bu romanında vezirin kızıdır. Bu bahis çalışmamızın ilerleyen kısmında ayrıntılı olarak ele alınacaktır.

${ }^{8}$ Tyzkaninon, özel olarak bu iş için eğitilmiş atlara binen oyuncuların, ellerindeki sopalarla yerdeki küçük taş topa vurarak oynadıkları bir oyundur. Amaç, topu, rakip sahadaki iki direğin arasından geçirebilmektir.
} 
İmparatorun sarayı gün oluyor bir cenaze evini andırıyordu. İçinde bir koşuşma, bir çırpınma, bir ağlaşma... Kederli, ümitsiz, sarı yüzler, anlaşılması güç fısıltılar... Gün oluyor, batmak üzere olan bir gemiyi andırıyordu. Herkes bir tarafa kaçışıyor, koca sarayda kedi köpek bile kalmıyordu. Köhne Bizans şehri, etrafını avcılar sarmış yağlı bir domuz yavrusuna benziyordu. Sağa koşsa, kaba etine dişlerini geçiren ve bir türlü doymayan Galatalı Cenevizliler, Venedikliler. Sola koşsa, elindeki kargısıyla ikide bir ensesine vuran Türkler. (Kozanoğlu, 1952, s. 146).

İncelediğimiz romanların ekseriyetinde İmparator Konstantin vatansever bir kahramandır. Başvezir Notaras ise bazı romanlarda vatansever, bazı romanlarda hain, bazı romanlarda da şehrin müdafaasına karşı çıkan, gereksiz yere maddi ve manevi bir zarar görmeden şehrin teslim edilmesini savunan bir devlet adamıdır. ${ }^{9}$

Bizans'ın yaşadığı korku ve içine düştüğü çaresizlik, bir takım halk inanışları oluşturmaya başlamıştır.

Aya Todozia Kilisesi'nin önünde bir ayin başlamıştır. Gözleri yaşlı genç kızlar, gözleri yaşlı ihtiyarlar vardır orada. Ağlayanlar, dua edenler, hıçkıranlar, diz çöküp Allah'a yalvaranlar vardır. Kürsüde konuşan bir papaz tatlı, kandırıcı bir sesle dinleyenlere:

-Korkmayın evlatlarım diyordu. Türkler şehirden içeri girseler bile, Çemberlitaş'a kadar yürüyecekler, orada bir melek gökten inip onları ta uzaklara sürecek. (Alpar, 1966, s. 244).

Bir başka romanda birinci tekil anlatıcı yaşanan korkuyu şöyle anlatı̧ştır:

Artık korkmamıza gerek yoktu. Ayasofya'ya gelmiştik. Başmelek Mikhael, kılıcını çekerek barbarları Forum Konstantini'nin önünde durduracak, oradan onları ta Kızıl Elma'ya dek ebediyen sürecekti. Büyük kiliseye girebilmek için herkes birbirini eziyordu. Atrium ${ }^{10} \mathrm{daki}$ aslan başlı havuza düşmüş birkaç kişiyi suyun içinde çırpınırken gördüm. “Az sonra onları karşılayacak olan sondan önce, günahlarını son bir kez daha yıkamak, arınmak istiyorlar diye düşündüm. İçeride insanları çldırtmaya yeten korku dalgası bende nedense yoktu. Son bir darbe kapıyı parçalayacaktı sanki. Okuldayken bize İmparator İustinianos'un (482565) bin yıl önce, bu kapının ahşap kanatlarını Nuh'un gemisinin kalıntılarında yaptırdığını söylemiş̧lerdi. Kapının mermer çerçevesinin üzerine de Azize Euphemia'11'nın lahdi yerleştirilmişti. "Zavallı Türkler bunları bilmiyor. Kapıyı kırdıklarında azizenin lahdi tepelerine düşerek, onları ezecek. Nuh da yeni bir tufanla hepsini boğacak" diye düşündüm. Sonra kendime acıdım. Ne yazık ki batıl inanç, Bizans ruhunun hep bir parçası olagelmişti. (Coral, 1998, s. 139).

\section{SONUÇ}

İstanbul'un fethinin ele alan tarihsel romanların çoğunda, fethin öncesinde dair surların her iki tarafına dair tespitlere rastlanmaktadır. Buralardan hareketle siyasi ve askeri sonuçlara, ekonomik ve toplumsal tahlillere ulaşılabilmektedir.

\footnotetext{
${ }^{9}$ Notaras'ın hain olduğu romanlarda, bu duruma karşılık olarak Çandarlı Halil Paşa da haindir. Bu romanlarda Notaras, hem canını hem de bir köşeye bucağa saklayabildiği paralarını kurtarmayı ummaktadır.

${ }^{10}$ Eski Roma yapıtlarında üstü açık yapılarına verilen ad

11 MS. 4. yüzyılda yaşamış bir Hristiyan kadındır. Döneminde henüz pagan inancına sahip Romalılar tarafından işkenceyle öldürüldüğ̈une inanılmıştır.
} 
Açıkça görülmektedir ki 29 Mayıs 1453'e varan süreçte Osmanlı cephesi daha istekli ve hazırlıklıdır. Hem sarayda hem de Edirne sokaklarında büyük bir coşku ve istek vardır. Genç Padişah Sultan Mehmet, fethin arkasındaki siyasi-askeri kadro ve bunlara ilaveten ilmi ve manevi şahıslar fethe tam olarak hazırlıklıdır. Hazırlıklar daha çok teknik ve askeri alanda yapılmıştır. Teknik hazırlıklardan en çok dikkat çekenler Rumeli Hisarı'nın inşası, Urban Usta direktörlüğünde topların dökümü ve donanmanın ıslah çalışmalarıdır. Siyasi hazırlıklar bağlamında ise Karaman Beyliği üzerine yürünüp Doğu sınırlarında güvenliğin temin edilmesini, Mora ve bazı adalardaki Venedik ve Ceneviz unsurlarıyla yapılan karşılıklı centilmenlik antlaşmalarını ve Macarlar başta olmak üzere Batı'daki diğer Hristiyan unsurlarla ilişkileri sakinleştirmeye yönelik barışçı adımların atılmasını örnek olarak verebiliriz. Yapılan askeri hazırlıklar ise yeniçeri ocağının talim ve terbiyesinin temin edilmesi, şımaran bazı ocaklara hadlerini bildirecek türden cezaların verilmesi, Rumeli ve Anadolu bölgesinden gönüllülerin getirtilmesi ve İstanbul çevresindeki bazı ufak kale ve adaların fethi şeklindedir.

Diğer taraftan surların içinde, yani Bizans cephesinde bambaşka bir dünya yaşanmaktadır. Kral, başvezir ve diğer askerî erkân, genç padişah Mehmet'i hafife almaktadır. Sarayın içinde zevk ve sefa saltanat sürmekte, dışında ise tam bir fakirlik ve çaresizlik görülmektedir. Kimse yaklaşan tehlikenin farkında değildir. Bunlara ilaveten hem saray içinde hem de İstanbul sokaklarında toplum ahlaken tefessüh etmiş durumdadır. Aklı başında olan birkaç kişiyi de kimsenin dinleyecek hâli yoktur. Fethe iyice yaklaşıldığı aylarda bazı tedbirler alınmış olsa da artık iş işten geçmiştir. Kader ağlarını örmüştür ve İstanbul için sona yaklaşılmaktadır.

Bizans tarafı tehlikenin farkına çok geç varmışsa da, Sultan Mehmet'in niyetinin anlaşılmasından sonra Edirne'ye gönderilen casuslar vasıtasıyla bilgi toplama faaliyetlerinin yapıldığı görülmektedir. Bu arada Bizans sarayının toplantı salonlarında yüksek seslerle Katolik ve Ortodoks kiliselerinin birleştirilerek tehlikenin bertaraf edilmesi planları yapıldığı görülmüştür. Ancak gerek mezhep farklılı̆gı ve gerekse 1204'teki Katolik zulmünün getirdiği güvensizlikler nedeniyle, emrindeki birkaç bin askerle son anda şehrin savunması için koşup gelen Giustiniani hariç, bu anlamda bir güç birliğinin sağlanamadığı görülmüştür. Şehrin savunmasına yönelik olarak da surların tamir edilmesi gibi ufak çaplı askeri hazırlıkların yapıldığını belirtmeliyiz.

Nihayet Nisan ayının başında muhasara başlamış ve elli iki günün sonunda, 1453 Mayıs'ının 29. Günü, Osmanlı orduları surları aşıp şehre girerek fethi gerçekleştirmiştir.

\section{KAYNAKÇA}

Ahmet Mithat, (1875). Hüseyin Fellah. İstanbul: Kırkanbar Matbaası.

Ahmet Mithat, (1877). Süleyman Muslî. İstanbul: Kirkanbar Matbaası.

Ahmet Ümit, (2012). Sultanı Öldürmek. İstanbul: Everest Yayınları.

Akman, Beyazıt (2012). Dünyanın İlk Günü. İstanbul: Epsilon Yayınları.

Altınyelekçioğlu, Ceyhun (2012). Güneşin İmparatoru Fatih. İstanbul: Artemis Yayınları.

Argunşah, Hülya (1990). Türk Edebiyatında Tarihi Roman. Yayımlanmamış Doktora Tezi. İstanbul:

Marmara Üniversitesi.

Argunşah, Hülya (2002). “Tarihî Romanın Yükselişi”, Hece (Türk Romanı Özel Sayısı), s. 65-67. 
Boyunağa, Ahmet Y1lmaz (1985). Korkusuz Cengâver. İstanbul.

Coral, Mehmet (1998). Bizans'ta Kayıp Zaman. İstanbul: Doğan Kitap.

Coral, Mehmet (1999). Konstantiniye'nin Yitik Günceleri. İstanbul: Doğan Kitap.

Çelik, Yakup (2002). “Tarih ve Tarihî Roman Arasındaki İlişki”, Bilig, S. 22, s. 65-67.

Çıracıoğlu, Vecdi (1999). Kara Büyülü Uyku. İstanbul: Can Yayınları.

Danışman, Zuhuri. (1970). Fatih Sultan Mehmet, İstanbul: Zuhuri Danışman Yayınevi.

Dayanç, Muharrem (2009). "Yeni Türk Edebiyatı Kaynağı Olarak Tarih ve Tarihî Eleştiri”, Turkish Studies, C. IV.

Doğanay, Mehmet (1998). Ahmed Midhat Efendi'nin Romanlarında İstanbul. Yayımlanmamış Yüksek Lisans Tezi. İstanbul: İstanbul Üniversitesi.

Erman, Murat (1998). Beyazateş Adası. İstanbul: Telo Yayınları.

Göğebakan, Turgut (2004). Tarihsel Roman Üzerine. Ankara: Akçağ Yayınları.

Gürsel, Nedim (1995). Boğazkesen-Fatih'in Romanı. İstanbul.

Hüseyin Latif (2008). İstanbul Düşerken. İstanbul: Bizim Avrupa Yayınları.

Kara, Halim (2012). Osmanlının Edebi Temsili: Türk Romanında Fatih. İstanbul: Hat Yayınları.

Kongar, Emre (1999). Hocaefendinin Sandukası. İstanbul: Remzi Kitabevi.

Kozanoğlu, Abdullah Ziya (1952). Fatih Feneri, İstanbul: Atlas Kitabevi.

Lukacs, György (2008). Tarihsel Roman (Çev. İsmail Doğan). Ankara: Epos Yayınları.

Moralızâde Vassaf Kadri, Şimal Rüzgârları, (Haz: Zeki Taştan), Akçă̆ Yayınları. Ankara 2006 (ilk yayım y1l 1915)

Namık Kemal, (1880). Cezmi, İnkılap Yayınevi, 1992 (ilk yayım yılı 1880).

Sepetçioğlu, Mustafa Necati (1980). Ebem Kuşă̆ı. İstanbul: İrfan Yayınevi.

Sepetçioğlu, Mustafa Necati (1980). Sabır. İstanbul: İrfan Yayınevi.

Sepetçioğlu, Mustafa Necati (1980). Gece Vaktinde Gündönümü. İstanbul: İrfan Yayınevi.

Sertelli, İskender Fahrettin (1930). Bizans'ın Son Günleri, İstanbul: Muallim Ahmet Halit Kütüphanesi.

Subaşı, Ebubekir (2013). Tarihin Dönüm Noktası: Fatih Sultan Mehmet. İstanbul: Mavi Lale Yayınları.

Şapolyo, Enver Behnan (1953). Fatih İstanbul Kapılarında, İstanbul: Rafet Zaimler Yayınevi.

Şehbenderzâde Filibeli Ahmet Hilmi, (1908). Öksüz Turgut. İstanbul.

Taştan, Zeki (2005). “Türk Romanında İstanbul'un Fethi ve Fatih”, Türk Edebiyatında İstanbul'un Fethi ve Fatih. İstanbul: Kitabevi Yayınları.

Tepedenlioğlu, Nizamettin Nazif (1928-1930). Kara Davut. İstanbul: Türkiye Matbaası.

Tuğcu, Kemalettin (1972). Bizans Yikılıyor, İstanbul: İtimat Kitabevi.

Türkeş, Ömer (2002). “Romana Yazılan Tarih”, Toplum ve Bilim, S. 91, s. 166-213.

Uğurcan, Sema (1995). "Ahmet Mithat Efendi'nin Romanlarında Tarih ve Medeniyet", Türk Dili Dergisi, s. 521-528.

Wellek, Rene vd. (1983). Edebiyat Biliminin Temelleri. Ankara: Kültür ve Turizm Bakanlığı Yayınları. 


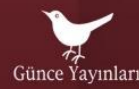

Prof. Dr. Önder Göçgün

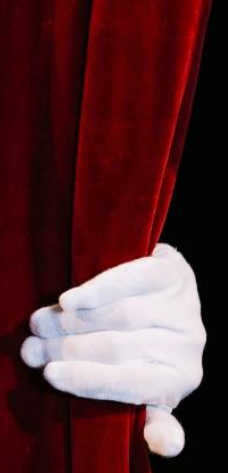

TIYYATRO DENEN HAYAT

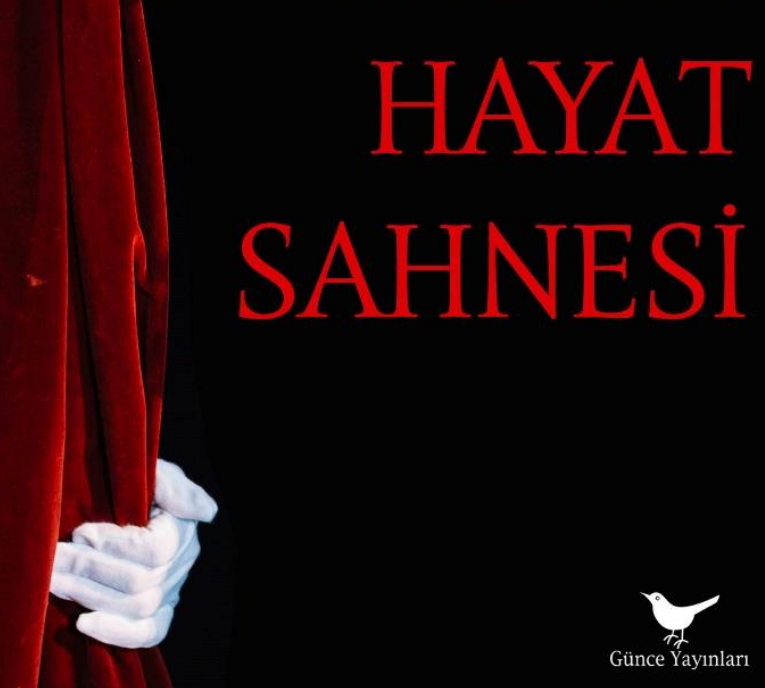

MUIIARREM DAYANC OKTAY YIVLI MACI'I BALIK MAIIMU'I BABACAN SLVIM SLERMEI
YASFMIN MUMCU BLDI் KOÇАKOĞLU NILÜLLLR ILLHAN MAKSUT YIĞITBAS SLL $\triangle M I I L \Lambda N$

\section{EDEBIYATINDA

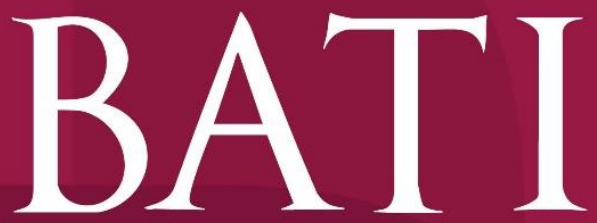 \\ EDEBIYATINDA
AKIMLAR \\ $\underset{\substack{\text { EDEBIYATINDA } \\ \text { AKIMLAR }}}{\mathrm{B} A T \mathrm{~T}}$}

editör

OKTAY YIVLI

HATICE FIRAT

YASEMIN MUMCU

OKTAY YIVLI

OĞUZHAN KARABURGU

BERNA AKYÜZ SIZGEN

NILÜFER ILHAN
ÜMMÜHAN TOPÇU

SEFA YÜCE

HANIFI ASLAN

METIN AKYÜZ

MEHMET SÜMER
YAKUP ÖZTÜRK
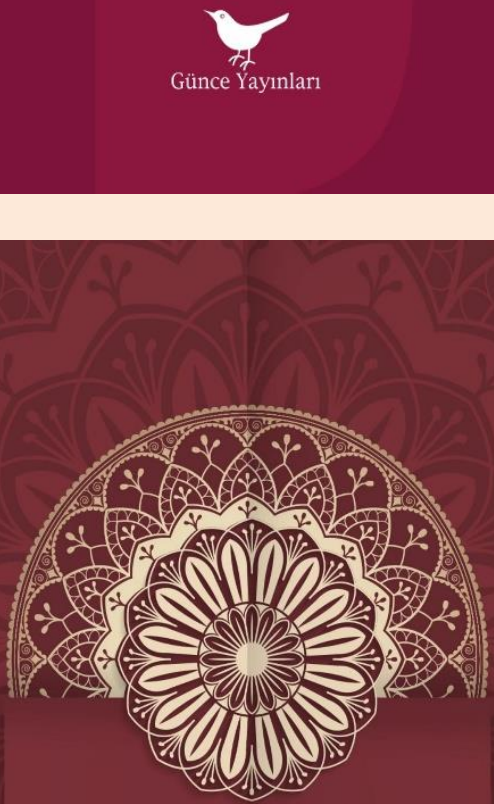

PROF. DR. ÖNDER GÖÇGÜN

$$
\begin{gathered}
\text { Türk } \\
\text { Tasavvuf } \\
\text { Siini }
\end{gathered}
$$

AÇIKLAMALI VE YORUMLU ÖRNEKLERLE 